\title{
Pengaruh Latihan Fisik Terhadap Kebugaran Lansia Dalam Masa Pandemi Covid-19 : Narrative Review
}

\author{
${ }^{1}$ Restu Anuar , ${ }^{2}$ Dika Rizki Imani, ${ }^{3}$ Siti Nadhir Ollin Norlinta \\ Program Studi Fisioterapi S1 Fakultas Ilmu Kesehatan Universitas 'Aisyiyah \\ Yogyakarta, JalanSiliwangi, Yogyakarta, Indonesia. \\ Email : restubintianuar@gmail.com
}

Tanggal Submisi: 23 Maret 2021; Tanggal Penerimaan: 21 Juni 2021

\begin{abstract}
ABSTRAK
Tujuan Penelitian: Untuk mengetahui pengaruh latihan fisik terhadap kebugaran lansia dimasa pandemi covid-19 dan macam-macam latihan fisik beserta dosisnya.

Metode Penelitian: Metode yang digunakan Narrative Review dan mengidentifikasi research question dengan framework PICO. Identifikasi artikel yang publikasi dari tahun 2010-2020 berkaitan dengan Latihan fisik terhadap kebugaran lansia dengan menggunakan database yang relevan (Pubmed, Science Direct, Google schoolar) dengan kata kunci yang telah ditentukan.Seleksi artikel menggunakan Critical Appraisal setelah itu dimasukkan ke dalam prisma flowchart.

Hasil: Berdasarkan 10 jurnal penelitian yang telah dilakukan sebelumnya mengenai Latihan Fisik terhadap kebugaran lansia ada pengaruh latihan fisik terhadap kebugaran lansia.

Kesimpulan: Ada pengaruh latihan fisik terhadap kebugaran lansia dalam masa pandemi covid-19.

Kata Kunci : Latihan Fisik, Kebugaran Lansia
\end{abstract}

\section{ABSTRACT}

Purpose: This study aims to determine the effect of physical exercise on the fitness of the elderly during the Covid-19 pandemic and various types of physical exercise and their dosage.

Methodology: Narrative Review was employed as the method of the study. Meanwhile, research questions were identified using the PICO framework. Articles published from 2010-2020 related to physical exercise on the fitness of the elderly were identified from relevant databases (PubMed, ScienceDirect, Google Scholar) with predetermined keywords. The selection of articles was conducted using Critical Appraisal before being inputted to a flowchart prism.

Results: Based on 10 research journals that had been conducted previously concerningphysical exercise on the fitness of the elderly, they suggest that there is an effect of physical exercise on the fitness of the elderly.

Conclusion: There is an effect of physical exercise on the fitness of the elderly during the Covid-19 pandemic

Keywords: Physical Exercise, Elderly Fitness 


\section{PENDAHULUAN}

Pada Desember 2019, kasuspneumonia misterius pertama kali dilaporkan di Wuhan, Provinsi Hubei. Sumber penularan kasus ini masih belum diketahui pasti, tetapi kasus pertama dikaitkan dengan pasar ikan di Wuhan. Tidak sampai satu bulan, penyakit ini telah menyebar di berbagai provinsi lain di China, Thailand, Jepang, dan Korea Selatan (Susilo, adityo dkk 2020). Virus inidikenali oleh orang saat ini yaitu COVID-19 atau Corona Virus Disease 2019 yang disebabkan oleh kelompok corona virus. Corona Virus adalah kumpulan virus yang bisa menginfeksisistem pernapasan (Hammami et al, 2020).

Di Italia, 85,6\% korban yang meninggal dunia akibat virus Covid- 19 ini berusia diatas 70 tahun. Hal ini terjadi akibat belum adanya vaksin yang mumpuni untuk mengobati pasien yang positif menderita Covid 19 (Syahruddin,2020).

Saat ini, pandemi Virus COVID-19 telah menyebar di 102 Negara. Di Indonesia, Kasus positif COVID-19 pertama kali dideteksi pada 2 Maret 2020, ketika dua orang terkonfirmasi tertular dari seorang warga negaraJepang. Pada 9 April, pandemi sudah menyebar ke 34 provinsi dimana Jakarta, Jawa Timur, dan Sulawesi Selatan sebagai provinsi palingterpapar.

Sampai saat ini di Indonesiatanggal 10 April 2020 telah memakan Korban 306 jiwa. Pada tanggal 15 Juni2020, Indonesia telah melaporkan 39.294 kasus positif, sehingga menempati peringkat kedua terbanyak di Asia Tenggara setelah Singapura dan sebelum Filipina Sedangkan di DIY mencatat kasus pertama tanggal 15 Maret 2020. Sampai dengan 10 Juni 2020, dilaporkan sebanyak 250 orang telah terkonfirmasi positif (Dinkes DIY, 2020).

Proses menjadi tua adalah satu fase dalam siklus hidup seseorang dengan karakteristik ditemukan adanyapenurunan setiap fungsi organ tubuh, seperti kondisi fisik, emosional, psikologik dan kemampuan sosial yang semakin lemah yang secara kesatuan menyebabkan penurunandaya tahan tubuh sehingga seorang lansia menjadi rentan terhadap berbagai serangan penyakit. Perubahan tersebut pada umumnyamenyebabkan kemunduran kesehatan fisik dan psikis yang pada akhirnyaakan berpengaruh pada kemampuan aktivitas seharihari lansia(activity of daily living) (Yanti dkk, 2020).

Juru bicara kementrian kesehatan dr. Achmad Yurianto, Direktur Jenderal P2P dan sebagai Ketua Gugus menyebutkan beberapa kasus pasien COVID-19 yang meninggalberada pada rentang usia sekitar 45 sampai dengan 65 tahun (Tosepu et al., 2020).

Proses penuaan yang dialami lansia menyebabkan kelompok ini menjadi salah satu kelompok yang mengalami efek paling parah akibat COVID-19 dan memiliki kerentanan yang lebih besar terinfeksi virus corona dibandingkan dengan usia muda (Susilo dkk, 2020).

Dalam mengatasi sebaran virus ini, pemerintah menganjurkan agar semua masyarakat melakukan social distancebahkan physical distance untuk mencegah penularan virus. Umumnya orang yang berusia lebih dari 65 tahun harus tinggal di rumah untuk menghindari risiko kontaminasi.Tetapi tindakan ini akan berdampak negatif pada lansia yaitu pada perilaku aktivitas fisik, dengan lebih banyak waktu dihabiskan untuk duduk, menonton, bersandar, atau berbaring lebih dari 8 jam per hari, kecuali untuk periode tidur , cenderung kurang bergerak, meningkatkan kurangnyaaktivitas fisik dan perilaku menetap, sehingga menurunkan kebugaran fisik dan dampak selanjutnya pada kesehatan fisik, kesejahteraan,pola tidur dan kualitas hidup (A. Hammamidkk, 2020).

Kurangnya aktivitas fisik terkaitdengan periode perilaku menetap yang lebih lamajuga dapat menyebabkan morbiditas dan mortalitas kardiovaskular karena semua penyebabnya. Individu yang aktif secara fisik secara signifikan mengurangi angka kematian akibat penyakit kardiovaskular, bahkan dengan perilaku tidak bergerak yang lama, karena mereka meningkatkan kebugaran kardiorespirasi dan mencegah berbagai penyakit kronisdan mereka mungkin menderita penurunan organ dan 
kognitif yang dipercepat, termasuk kemungkinan jatuh karena ketidakseimbangan postural (pinho et al, 2020)

Kebugaran fisik merupakan salah satu tolak ukur dalam menentukan derajat kesehatan termasuk lansia, dengan kebugaran maka seseorang mampu melakukan aktivitas fisik dalam pekerjaan sehari-hari, karena aktivitas fisik terkait dengan kemampuan fungsional termasuk mobilitas dan kemandirian dalam aktivitas pribadi dalam kehidupan sehari-hari tanpa menimbulkan kelelahan fisik yang berlebihan dan masih dapat melakukan kegiatan lainnya (Pinho et al. 2020).

Kebugaran fisik adalah kemampuanuntuk memenuhi tuntutan mempertahanakan keselamatan hidupsehari-hari dan efektif tanpa mengalami kelelahan dan masih memiliki energi untuk melakukan aktifitas lainnya dan kegiatan rekreasi (Astuti, 2017). Penting bagi orang yang lebih tua / lansia untuk tetap aktifdan menjaga serta meningkatkan status kesehatan mereka (Lakicevic, 2020).

Pada lansia kebugaran jasmani dapat dipertahankan dengan latihan fisik yang teratur sejak dini, dan melaksanakan pola hidup sehat (Nuraeni et al, 2019).

Latihan fisik atau exercise lebih merujuk pada aktivitas fisik yang terencana, terstruktur, dan gerakan berulang untuk memperbaiki atau memelihara kebugaran tubuh (Gahete et al,2017). Orang yang lebih tua atau lansia disarankan untuk memanfaatkan latihan fisik dalam mengurangi penyakit menular, termasuk patologi virus (da Silveira, 2020). Mengingat keadaan saat ini, banyak lansia yang hanya dapat melakukan latihan fisik di lingkungan rumah (Cunningham et al, 2020).

Namun karena wabah virus corona yang menyerang dunia dan sampai di indonesia, penulis tidak bisa memberikan intervensi latihan fisik secara langsung kepada responden sehingga efektivitas intervensi ini akan dianalisis berdasarkan sumberkepustakaan atau beberapa jurnalilmiah Narrative Review.

\section{METODOLOGI PENELITIAN}

Metode penelitian yang digunakan adalah narrative review. Artikel penelitian didapatkan dari tiga database yaitu Pubmed, science direct, dan google schooler. Pencarian artikel menggunakan kata kunci dilakukan menggunakan format PICO, yaitu P : Population (Lansia), I : Intervention(Latihan Fisik), C : Comparison (Intervensi atau exercise lainnya) dan O : Outcome (Kebugaran Lansia). Kriteria inklusi yang ditetapkan adalah: 1) Artikel yang berisi full text, 2) Artikel dalam bahasa Inggris danindonesia, 3) Article dalam 10 tahun terakhir (2010-2020), 4) Artikel dengan objek penelitian Manusia, 5) Tempat penelitian nasional dan internasional 6) Artikel Lansia dan Fisioterapi 7) Artikel tentang latihanfisik 8) Artikel tentang kebugaranLansia 9) Artikel lansia dan covid-19, 10) Artikel dengan responden lansialaki-laki dan wanita umur 60 keatas.

Dari 10,576 artikel yang teridentifikasi berdasarkan kata kunci, 10 artikel diantaranya direview dalam penelitian ini. Hasil dari pencarian digambarkan dalam sebuah bagan PRISMA Flow Diagram dan penulis memetakannya ke dalam bentuk matriks.

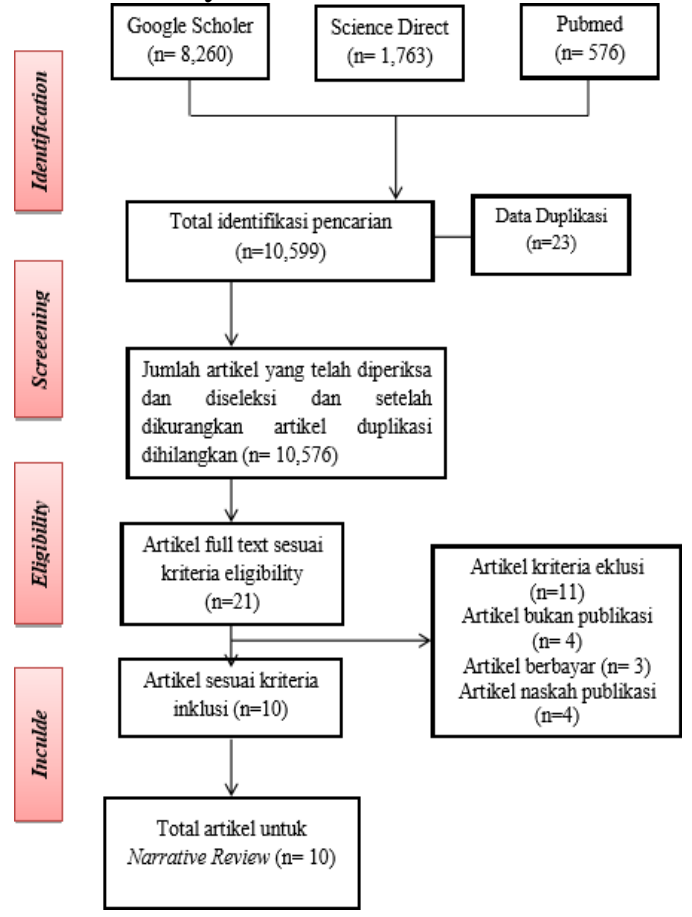

Gambar 1 PRISMA Flow Diagram 
HASIL

Tabel 1. Hasil penelitian dalam artikel yang direview

\begin{tabular}{|c|c|}
\hline $\begin{array}{c}\text { Judul / Penulis / } \\
\text { Tahun }\end{array}$ & Tahun Hasil \\
\hline $\begin{array}{l}\text { Kebugaran Jasmani Bagi } \\
\text { Lansia Saat Pandemi } \\
\text { Covid-19. }\end{array}$ & $\begin{array}{l}\text { Latihan aerobik memberikan pengaruh antara lain } \\
\text { menurunkan kerawanan terhadap penyakit jantung, } \\
\text { menurunkan tekanan darah bagi penderita hipertensi, } \\
\text { menurunkan kadar lemak tubuh, menurunan depresi dan } \\
\text { kecemasan, dapat menanggulangi penyakit mental, } \\
\text { sertamengurangi resiko penyakit tulang dan memiliki efek } \\
\text { yang signifikan bagi pengembangan kebugaran lansia }\end{array}$ \\
\hline $\begin{array}{l}\text { Effects of Elastic Band } \\
\text { Exercise on Functional } \\
\text { Fitness and Blood } \\
\text { Pressure Response in the } \\
\text { Healthy Elderly }\end{array}$ & $\begin{array}{l}\text { kekuatan genggaman, duduk dan meraih, danduduk } \\
\text { berdiridan one leg stance meningkat secara signifikandalam } \\
\text { kelompok latihan. sementara tidak ada peningkatan } \\
\text { signifikan yang ditemukan pada penyangga kursi dan } \\
\text { mengatur waktu dan pergi ( p < } 0,05) \text {. Parameter } \\
\text { kardiovaskular termasuk tekanan darah sistolik,tekanan } \\
\text { darah diastolik, tekanan arteri rata-rata, dan tekanan nadi } \\
\text { menurun secara signifikan pada kelompok latihan relatif } \\
\text { terhadap kelompok kontrol }(\mathrm{p}<0,05) \text {. }\end{array}$ \\
\hline $\begin{array}{l}\text { Physical Activity for } \\
\text { Improving the Immune } \\
\text { System of Older Adults } \\
\text { During the COVID-19 } \\
\text { Pandemic. }\end{array}$ & $\begin{array}{l}\text { Efek positif dari olahraga aerobic, seperti Pilates, yoga, } \\
\text { jalan kaki, jogging dan besepeda pada peningkatan efek } \\
\text { penuaan, sudah jelas.efek positifnya pada sistem } \\
\text { kekebalan, dapat digunakan sebagai strategi untuk } \\
\text { memperkuat sistem kekebalan orang dewasa yang lebih tua } \\
\text { terhadap COVID- 19, Gaya hidup aktif memiliki efek } \\
\text { positif pada penuaan sistem kekebalan dan komponen } \\
\text { kebugaran jasmani, termasuk kebugaran kardiorespirasi, } \\
\text { kekuatan otot, keseimbangan, koordinasi, dan ketangkasan } \\
\text { Tingkat intensitas latihan aerobik (sedang vs. tinggi) tidak } \\
\text { memberikan perbedaan yang signifikan terhadap respon } \\
\text { adaptif kebugaran kardiopernafasan pada populasi lansia. }\end{array}$ \\
\hline $\begin{array}{l}\text { Effects of aerobic } \\
\text { physical activity to } \\
\text { cardio-respiratory fitness } \\
\text { of the elderly population: } \\
\text { systematic } \\
\text { overview }\end{array}$ & $\begin{array}{l}\text { Pelatihan dalam durasi } 6 \text { minggu dapat secara signifikan } \\
\text { mempengaruhi peningkatan konsumsi oksigen maksimum, } \\
\text { tetapi durasi pelatihan yang lebih lama memiliki efek yang } \\
\text { lebih baik. Latihanketahanan memiliki efek yang serupa } \\
\text { dengan peningkatan kebugaran pernafasan kardio baik pada } \\
\text { pria maupun wanita. Di sisi lain, tampaknya orang aktif } \\
\text { memiliki respons adaptif yanglebih rendah dibandingkan } \\
\text { dengan orang yang tidak banyak bergerak ( } 8,3 \% \text { vs } \\
18,84 \%) \text {. } \\
\text { secara keseluruhan, PET menunjukkan efek yang besar } \\
\text { untuk meningkatkan kekuatan otot }(\mathrm{ES}=1,23) \text {, }\end{array}$ \\
\hline
\end{tabular}

The effects of Pilates

exercise training on 
Tabel 2. Hasil penelitian dalam artikel yang direview

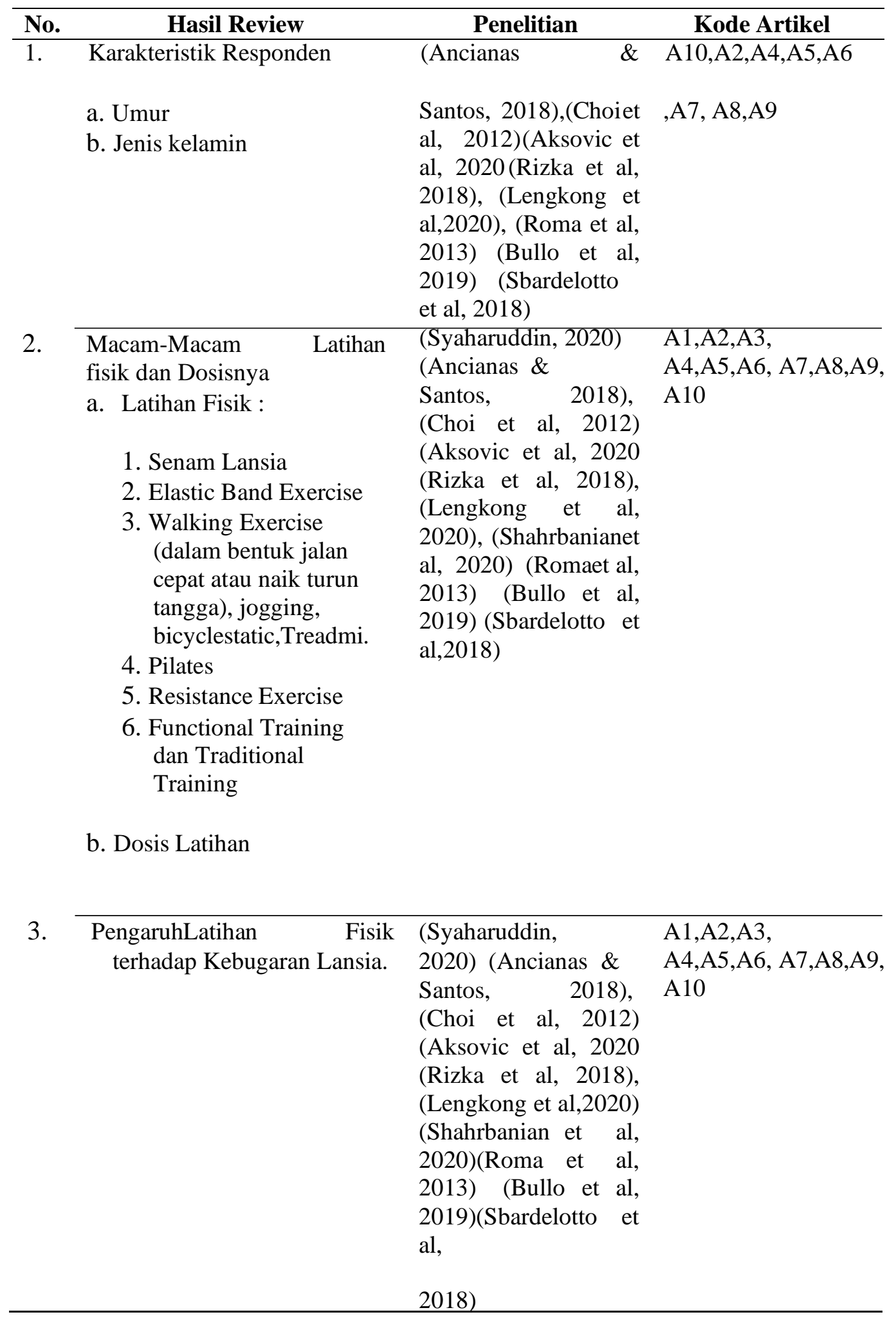




\section{PEMBAHASAN}

\section{Karakteristik Responden}

Berdasarkan 10 Artikel yang terpilih dari Pubmed, Scince Direct dan Google Scholer pada jurnal (A2,A4,A5,A6,A7,A8,A9,A10) terdapat karekteristik responden yaitu lansia dengan umur 60-89 tahun dan jenis kelamin laki-laki dan perempuan dan lebih dominan perempuan. Proses penuaan menyebabkan hilangnya massa otot secara kuantitatif (sarcopenia) dan penurunan kekuatan serta potensi otot. Puncak kekuatan otot terjadi antara dekade kedua dan ketiga kehidupan. Sampai usia 50tahun, terjadi sedikit penurunan kekuatan otot, yang mengalami stressetelah usia 65 tahun, kemudian menurun $12 \%$ hingga $15 \%$ untuk setiap dekade dan setelah mencapai usia 30 tahun terjadi penurunankebugaran jantung paru $1 \%$ setiap usia bertambah satu tahun.

Kebugaran jantung paru merupakan indikator pemakaian oksigen oleh jantung dan paru-paru dimana usia 60 tahun kebugaran jantung dan paru akan berkurang 35\%. Tingkat kebugaran antara lansia berjenis kelamin lakilaki dan perempuanterdapat adanya perbedaan tingkat aktivitas, gaya hidup, hormon, perbedaan biologis serta perbedaanperkembangan otot dan kekuatan otot. Lansia laki-laki ketika memasuki usia lanjut akan sedikit melakukan aktivitasdan kebanyakan duduk membaca koran dan menonton tv. Hal ini berbeda dengan perempuan meskipun sudah lanjut tetap melakukan aktivitas rumah tangga seperti memasak, menyiapkan masakan utuk keluarga.

\section{Macam-Macam Latihan Fisik danDosisnya}

Berdasarkan 10 artikel yang terpilihdari 3 database yaitu Google Scholer, Science Direct dan Pubmed terdapatmacam-macam latihan fisik dan dosisnya. Latihan fisik yang banyak diberikan pada lansia adalah type latihan fisik bersifat aerobic intensitas sedang, frekuensinya 2-3 kali seminggu, time selama 30-60 menit dengan intensitas menggunakan patokan kenaikan detak jantung (Training Heart Rate = THR) atau denyut nadi maksimal (HR max) (220-usia) antara 50\%-70\%.

Tabel 3 Dosis Latihan Fisik

\begin{tabular}{|c|c|c|}
\hline PENELITIAN & LATIHAN FISIK & DOSIS \\
\hline \multirow[t]{2}{*}{$\begin{array}{l}\text { (Syaharuddin, } 2020 \text { \& Lengkong } \\
\text { et al, 2019) }\end{array}$} & Senam Lansia & $\begin{array}{l}\text { 30-60 menit Usia } 60 \text { Tahun } \\
\text { berlatih dalam denyut nadi } \\
\text { 112-136/menit. 3-5 kali } \\
\text { seminggu }\end{array}$ \\
\hline & & $\begin{array}{l}30-40 \text { menit dengan } \\
\text { intensitas minimal 50\% } \\
\text { VO2max atau } 60 \% \text { Hrmax } 1 \\
\text { kali seminggu selama } 5 \\
\text { minggu atau 8-12 minggu. }\end{array}$ \\
\hline
\end{tabular}

\begin{tabular}{llll}
\hline (Choi & et al, $\quad$ & Elastic Band Exercise side lateral & 60 menit terdiri dari \\
& band raises,left and right shoulder & pemanasan 15 menit, latihan \\
& waves, band hammercurls, band utama 30 menit, dan \\
& curls,triceps bandextensions, & pendinginan 15 menit. \\
& triceps band kick-backs,band \\
& standing rows,band shoulder \\
& rotations, band squats, band dead \\
& lifts, standing bandtriceps \\
& extensions,standing band, \\
&
\end{tabular}




\begin{tabular}{|c|c|c|}
\hline & $\begin{array}{l}\text { chestpresser, upper bands,seated } \\
\text { band rows, bandleg raises, } \\
\text { holding legsprops, pelvis } \\
\text { relaxations, and bandcrunches. }\end{array}$ & \\
\hline Shahrbanianet al, 2020) & $\begin{array}{l}\text { Walking Exercise, Strair } \\
\text { climbing / naikturun tangga } \\
\text { Sepeda static }\end{array}$ & $\begin{array}{l}\text { 30-45 menit, 3-4 } \\
\quad \text { xseminggu } \\
\text { 2-3 kali seminggu 8-12 } \\
\text { pengulangan } \\
\text { 5-10 menit } 5-7 \text { seminggu }\end{array}$ \\
\hline (Aksovic et al,2020) & $\begin{array}{l}\text { Aerobic; walking, } \\
\text { jogging, bicycle }\end{array}$ & $\begin{array}{l}30-40 \text { menitdengan } \\
\text { intensitas minimal } \\
50 \% \text { VO2max atau } 60 \% \\
\text { Hrmax, } \\
3,5 \text { jam } 2 \text { atau } 3 \text { kali } \\
\text { seminggu. }\end{array}$ \\
\hline (Bullo2019) & Pilates & 1jam 3 hari seminggu \\
\hline $\begin{array}{l}\text { (Rizka et al } \\
2018)\end{array}$ & Resistance Exercise & 1 jam 2 kali seminggu \\
\hline $\begin{array}{l}\text { (Roma } \quad \text { et al, } \\
2013)\end{array}$ & $\begin{array}{l}\text { chest presses, rows, leg presses, } \\
\text { calf presses, sit-ups, and lower } \\
\text { backexercises. } \\
\text { Aerobic : exercisewalking }\end{array}$ & $\begin{array}{l}30 \text { menit } 2 \text { kali seminggu. } \\
\text { Denyut jantung (HR) diukur } \\
\text { setiap } 5 \text { menit dengan, } \\
\text { tujuannya untuk menjaganya } \\
\text { tetap antara } 60 \% \text { dan } 70 \% \\
\text { dari HR maksimal }\end{array}$ \\
\hline (Sbardelotto etal, 2018) & $\begin{array}{l}\text { Treadmill } \\
\text { (Aerobic } \quad \text { exercise intensitas } \\
\text { sedang) }\end{array}$ & $\begin{array}{l}30 \text { menit } 5 \text { kali perminggu } \\
\text { dan 5-10 menit terakhir } \\
\text { melakukan strecthing dan } \\
\text { mobilisasi sendi. }\end{array}$ \\
\hline $\begin{array}{l}\text { (Ancianas } \\
\text { Santos, 2018) }\end{array}$ & $\begin{array}{l}\text { - Functional Training } \\
\text { - Mobilitas sendi Sirkuit } \\
\text { training: } \\
\text { push up, lari bolakbalik } \\
\text { - Exercises untuk lower and } \\
\text { upper limbs dengan stabilizing } \\
\text { otot spine } \\
\text { - Traditional Training: } \\
\text { Mobilitas sendi } \\
\text { Senam aerobik }\end{array}$ & $\begin{array}{l}1-5 \text { menit } \\
2-15 \text { menit } \\
3-25 \text { menit } \\
1 \quad-5 \text { menit } \\
2 \quad-15 \text { menit }\end{array}$ \\
\hline
\end{tabular}




\section{Pengaruh Latihan Fisik Terhadap}

\section{Kebugaran Lansia Dalam MasaPandemi Covid-19}

Menurut jurnal (Syahruddin, 2020 dan lengkong et al, 2020) Menunjukkan bahwa Ada pengaruh Senam lansia terhadap kebugaran jantung paru lansia. Senam termasuk latihan fisik bersifat aerobic. Latihan fisik adalah proses mengembangkan kemampuan aktivitas gerak jasmani yang dilakukan secara sistematik serta ditingkatkan secara progresif untukmeningkatkan derajat kebugaran jasmani agar tercapai kemampuan kerja fisik yang optimal. Respons kardiovaskuler yang paling utama terhadap aktivitas fisik ialah peningkatan cardiac output.

Peningkatan ini disebabkan oleh isi sekuncup jantung maupun heart rateyang dapat mencapai sekitar 95\% dari tingkat maksimalnya. Karena pemakaian oksigen tubuh tidak dapat melebihi kecepatan sistem kadiovaskuler menghantarkan oksigen ke jaringan, maka dapat dikatakan bahwa sistem kardiovaskuler dapat membatasi nilai VO2max. Mengenai komposisi tubuh, konsumsi oksigen maksimal dinyatakan dalam beberapa milimeter oksigen yang dikonsumsi perkilogram berat badan, perbedaan komposisi tubuh seseorang menyebabkan konsumsi yang berbeda. Latihan aerobik memberikan pengaruh antara lain menurunkan tekanan darah bagi penderita hipertensi, menurunkan kadar lemak tubuh, menurunan depresi dan kecemasan, dapat menanggulangi penyakit mental, serta mengurangi resiko penyakit tulang, meningkatkan fleksibilitas dan daya tahan jantung paru. Dalam situasi wabah virus Covid-19, sebaiknya setiap individu mampu menjaga kebugarannnya termasuk lansia melalui senam yang sifatnya aerobik dengan harapan lansiadapat menunaikan tugas hariannya dengan baik dan tanpa mengalamikelelahan yang berlebihan.

Menurut jurnal penelitian (Choi et al, 2012) Menunjukkan bahwa program EBE saat ini dengan desain pelatihan sirkuit yang digabungkan memiliki efek positif pada kesehatan fungsional serta kardiovaskular. Program EBE yang aman, murah, dan mudah diakses dengan komponen pelatihan sirkuit memainkan peran penting dalam meningkatkan kebugaran tubuh bagian atas dan bawah, serta kebugaran

kardiovaskular, pada orang tua.

Menurut jurnal penelitian (Shahrbanian et al, 2020) Bahwa Aktivitas fisik sangat penting untuk menjaga kesehatan dan kemandirian orangdewasa yang lebih tua mempengaruhi sistem kekebalan dan melawan virus. Olahraga teratur meningkatkan sistem kekebalandengan mengurangi faktor inflamasi dan meningkatkan kapasitas antioksidan. Efek positif dari olahraga, seperti Pilates, pada peningkatan efek penuaan, sudah jelas. Latihan dianggap sebagai intervensi imunoterapi. Olahraga teratur, dengan efek positifnya pada sistem kekebalan, dapat digunakan sebagai strategi untuk memperkuat sistem kekebalan orang dewasa yang lebih tua terhadap COVID-19. Olahraga juga dapat mengurangi kelemahan dan kerapuhan pada orang dewasa yang lebih tua.

Program latihan rumahan meningkatkan aktivitas fisik, mobilitas, kekuatan otot, dan keseimbangan pada orang dewasa yang lebih tua. Selain itu, aktivitas fisik dapat mengaturkomposisi mikrobioma usus, yang mengarah pada penurunan kelemahan fisik.

Aktivitas fisik untuk orangdewasa yang lebih tua mencakup semua komponen kebugaran fisik, termasuk kebugaran kardiorespirasi, kekuatan otot, keseimbangan, koordinasi, dan kelincahan.

Menurut jurnal penelitian(Aksovic et al, 2020) Latihan dalam durasi 6 minggu dapat secara signifikan mempengaruhi peningkatan konsumsi oksigen maksimum, tetapi durasi pelatihan yang lebih lama memiliki efek yang lebih baik. Latihanketahanan memiliki efek yang serupa dengan peningkatan kebugaranpernafasan kardio baik pada pria maupun wanita. Di sisi lain, tampaknya orang aktif memiliki respons adaptif yang lebih rendah dibandingkan dengan orang yang tidakbanyak bergerak (8,3\% vs $18,84 \%$ ).

Menurut jurnal penelitian (Bullo et al, 2019) bahwa PET dapatmeningkatkan kekuatan, 
juga keseimbangan dinamis, kinerja berjalan pada populasi lansia. Selain itu, PET mungkin berguna dalam mengurangi risiko jatuh, meningkatkan kemandirian, kebugaran fisik, kualitas hidup, dan keadaan suasana hati.

Menurut jurnal penelitian (Rizka et al, 2018) Bahwa ada pengaruh latihan jalan kaki terhadap Kebugaran Jasmani Lansia. Jalan kaki adalahsuatu kegiatan fisik atau latian fisik yang menggunakan otot-otot terutama otot kaki untuk berpindah dari suatu tempat atau ketempat lain. Gerak tubuh yang kita lakukan saat berjalan didominasi oleh langkah kaki, meskipun gerakan tangan dan anggota badan lainnya juga diperlukan tetapi gerak langkah kaki sebagai gerak yang utama. Jalan kaki merupakan suatu latihan olahraga yang aman mudah dan murah juga memiliki banyak manfat bagi tubuh. Pada dasarnya aktivitas fisik yang dilakukan secara berkelanjutan dalam jangka waktu yang panjang dapat melatihkebugaranjasmani seseorang, begitu juga dengan jalan kaki. Selain melatih kebugaran jasmani,oksigen yang dihirup dan diedarkan saat berjalan kaki akan memperlancar sirkulasi darah sehingga tubuh menjadi lebih cepat lelah, tubuh dapat lebih cepat kembali ke kondisi normal dan dapat mengurangi stres atau depresi.

Menurut Jurnal penelitian (Roma et al, 2019)Bahwa aktivitas fisik resistance exercise dan aerobic exercisememiliki efek positif yaitu dapat meningkatkan kebugaran fisik dan pemeliharaan fungsional lansia. Menurut Jurnal penelitian(Sbardelotto et al, 2018) Menunjukkan Olahraga latihan fisik kombinasi (latihan aerobic dan kekuatan) berpengaruh terhadap kebugaran fungsional (kekuatan, daya tahan otot, fleksibelitas, kecepatan/ kelincahan, dan kebugaran aerobic) lansia. Latihankekuatan dan aerobik untuk populasi lansia paling efektif untuk meningkatkan fungsi neuromuskuler dan kardiorespirasi dan, akibatnya, mempertahankan kapasitas fungsional selama penuaan.

Pelatihan ketahanan aerobik menginduksi pusat dan peri adaptasipheral yang meningkatkan VO2 maks dan kemampuan otot rangka untuk menghasilkan energi melalui oksidatif metabolisme tanpa peningkatan bersamaan dalam kekuatan otot atauhipertrofi. Selain itu, perubahan osteoartikuler dan otot seperti perubahan keseimbangan yang disebabkan oleh waktu harus dipertimbangkan saat memilih lingkungan latihan dan jenis latihan. Olahraga teratur dapat meningkatkan kebugaran fisik dan selanjutnya, meningkatkan kemampuan untuk melakukan tugas di seluruh individuseumur hidup.

Menurut jurnal (Ancianas \& Santos, 2018) Kedua intervensi tersebut efisien untuk meningkatkan kebugaran fisik orang lanjut usia. Bahwa pelatihan fungsional (FT) meningkatkan keseimbangan / kelincahan yang signifikan, kekuatanekstremitas bawah, kekuatanekstremitas atas, kebugaran kardiorespirasi, dan kekuatan isometrik pada wanita lansia yang sehat bila dibandingkan dengan pelatihan tradisional. Latihan FT yang berbeda dapat mengaktifkan otot penstabil tulang belakang dengan lebih banyak intensitas dan merangsang pusat kendali postural, sehingga kondisi kelincahan dan keseimbangan dinamis dapat berkembang lebih efisien. Untuk adaptasi dalam kekuatan otot, latihan multiartikular bertindak mengintegrasikan struktur tubuh, menyebabkan aktivasi unit motorik yang lebih besar dan koordinasi intermuskuler yang dapat memungkinkan perpindahan ke aktivitas sehari-harimengintegrasikan struktur tubuh, sedangkan untuk kebugaran kardiorespirasi, karakteristik metabolik dari sirkuit fungsional meningkatperubahan dalam mekanisme yang bertanggung jawab untuk pengangkutan dan penggunaan oksigen, peningkatan kapasitas oksidatif sel otot, dan degradasi glikogen dan fosfat.

\section{KESIMPULAN}

1. Ada pengaruh latihan fisik terhadapkebugaran lansia dimasa pandemi covid-19

2. Terdapat macam-macam latihan fisik seperti senam, pilates, walking exercise, teraband exsrcise,sepeda static, jogging, treatmill.

3. Terdapat juga berbagai dosis latihan fisik yaitu 1 jam perhari dalam waktu seminggu, 2 hari ataulebih per minggu, 3 set $10-12$ pengulangan, 10-30 menit, 3-4 kali 
pengulangan, Selama 5-10 menit dan 5-7 hari dalam seminggu, $2 \mathrm{x}$ seminggu selama 10 menit, 3 hariperminggu,30-40 menit 1 kaliseminggu selama 5 minggu atau 8-12 minggu.

\section{SARAN}

1. Profesi Fisioterapi

Diharapkan Narrative Review ini dapat dijadikan sebagai bahan untuk pengembangan pengetahuanilmu Fisioterapi dalam pencegahan atau penatalaksanaan kebugaran fisik lansia dimasa pandemi covid-19 dengan latihan fisik. Promosi kesehatan dapat dilakukan untuk memberikan Edukasi kepada masyarakat bahwa latihan fisik dapat dijadikan home program padalansia dimasa pandemi covid19.

2. Peneliti Selanjutnya

Diharapkan penelitian inidikembangkan oleh peneliti selanjutnya dan lebih banyak menambahkan literature yang membahas tentang pengaruh latihan fisik terhadap kebugaran lansia dimasa pandemi covid-19.

3. Bagi Masyarakat

Diharapkan penelitian inidijadikan referensi sebagai bentuk pencegahan dampak dari kurangnya aktivitas fisik atau intervensi dalam meningkatkan kebugaran baik pada lansia maupun pada yang orang muda.

\section{DAFTAR PUSTAKA}

Alhashem, H., Al-hamrani, A., Alhejji, E., \& Alrufayi, A. (2020). COVID 19 Infection and the Risk to the Elderly. A Narrative Review,(July).

Amaro Gahete, F. J., De La O, A., Jurado Fasoli, L., Castillo, M. J.,\& Gutierrez, A. (2017). Fitness Assessment as anAnti-Aging Marker: A Narrative Review. Journal of Gerontologi \& Geriatric Research, 06(06). https://doi.org/10.4172/2167-

\subsection{5}

Ancianas, F. D. E., \& Santos, M. S. (2018). Effects of differentneuromuscular training protocols on the functional capacity of elderly women, 24(2), 140-144.

Aksović, N., Bjelica, B., Joksimović, M., Skrypchenko, I., Filipović, S., Milanović, F., Pržulj, R. (2020). Effects of aerobic physical activity to cardio-respiratory fitness of the elderly population: systematic overview. Pedagogy of Physical Culture and Sports, 24(5), 208-218. https://doi.org/10.15561/2664983 7.2020 .0501

Bullo, V., Bergamin, M., Gobbo, S., Sieverdes, J. C., Zaccaria, M., Neunhaeuserer, D., \& Ermolao, A. (2015). The effects of Pilates exercise training on physical fitness and wellbeing in the elderly: A systematic review for future exercise prescription. Preventive Medicine, 75, 111. https://doi.org/10.1016/j.ypmed.2 015.03.002

Choi, H. M., Hurr, C., \& Kim, S. (2020). Effects of elastic band exercise on functional fitness and blood pressure response in the healthy elderly. International Journal of EnvironmentalResearch and Public Health, 17(19), 1 10.https://doi.org/10.3390/ijerph17197144

da Silveira, M. P., da Silva Fagundes, K. K., Bizuti, M. R., Starck, É.,Rossi, R. C., \& de Resende e Silva, D. T. (2020). Physicalexercise as a tool to help the immune system against COVID- 19: an integrative review of the current literature. Clinical and Experimental Medicine, 2019(0123456789). https://doi.org/10.1007/s10238-

02000650-3

Hambali, R. M., Kusmaedi, N., \& Jajat. (2019). Tingkat Kebugaran Jasmani Lansia 
Dikaji Berdasarkan Tingkat Partisipasidan Gender. Jurnal Keolahragaan, 5(2), 1-11.

Lakicevic, N., Moro, T., Paoli, A., Roklicer, R., Trivic, T., Cassar, S., \& Drid, P. (2020). Stay fit, don't quit: Geriatric Exercise Prescription in COVID-19 Pandemic. Aging Clinical and Experimental Research, 32(7), 1209-1210. https://doi.org/10.1007/s40520-020-01588y

Lengkong, G., Marunduh, S. R., \&Wungow, H. I. S. (2016).

Pengaruh senam bugar lansia terhadap kebugaran jantung paru di Panti Werdha Bethania Lembean. Jurnal E-Biomedik, 4(2).https://doi.org/10.35790/ebm. 4.2.2016.14014

Nuraeni, R., Akbar, M. R., \& Tresnasari, C. (2019). Pengaruh Senam Lansia terhadap Tigkat Kebugaran Fisik pada Lansia Berdasar atas Uji Jalan 6 Menit.Jurnal Integrasi Kesehatan \& Sains,1(2),121-126. https://doi.org/10.29313/jiks.v1i2.4633

Permenkes RI. (2015). Penyelenggaraan PelayananKesehatan Lanjut Usia Di Pusat Kesehatan Masyarakat. Kementrian Kesehatan Indonesia, 1-140.

Rizka, M., \& Agus, A. (2018). Pengaruh Latihan Jalan Kaki Terhadap Kebugaran Jasmani Lansia Di Puskesmas Sungai Aur Kabupaten Pasaman Barat. Jurnal Stamina, 1(1), 206-218. Retrieved from file:///D:/ANALISIS BAB VVII/SKRIPSI 2019-2020/project skripsi/moni proposal/Jurnal/53-Article Text68-

\section{1-10-20190123.pdf}

Roma, M. F. B., Busse, A. L., Betoni, R. A., Melo, A. C. de, Kong, J.,Santarem, J. M., \& Jacob Filho,W. (2013). Effects of resistance training and aerobic exercis in elderly people concerning physical fitness and ability: a prospective clinical trial. Einstein (São Paulo, Brazil), 11(2), 153- 157. https://doi.org/10.1590/S1679. 45082013000200003

Sbardelotto, M. L., Costa, R. R.,Malysz, K. A., Pedroso, G. S., Pereira, B. C., Sorato, H. R., ... Pinho, R. A. (2019). Improvementin muscular strength and aerobic capacities in elderly people occurs independently of physical training type or exercise model. Clinics, 74(7). https://doi.org/10.6061/clinics/2019/e833

Shahrbanian, S., Alikhani, S., Ahmadi Kakavandi, M., \& Hackney, A. C. (2020). Physical Activity forImproving the Immune System of Older Adults During the COVID-19 Pandemic. Alternative Therapies in Health and Medicine,26(S2), 117-125

Susilo, A., Rumende, C. M., Pitoyo, C. W., Santoso, W. D., Yulianti, M., Herikurniawan H., Yunihastuti, E. (2020).Coronavirus Disease 2019:Tinjauan Literatur Terkini. Jurnal Penyakit Dalam Indonesia, $\quad 7(1), \quad 45$. https://doi.org/10.7454/jpdi.v7i1.4 15 Syahruddin, S. (2020). Kebugaran Jasmani Bagi Lansia Saat Pandemi Covid-19. JUARA :Jurnal Olahraga, 5(2), 232-239. 